of compiling a list was assigned to the British Commonwealth of Nations Scientific Liaison Office in London, and it has now published the required information in a book called "The Commonwealth Post-Graduate Scholarships in Science". Since the main objective of the list is to encourage the movement of scientific workers within the Commonwealth, only those awards open to members of at least one Commonwealth country or Colony other than the awarding one have been included. The entries are set out in tabular form showing, in addition to the names of the scholarships and the agencies awarding them, details of the fields of study, where tenable, duration and value, closing dates for applications and the addresses to which these should be sent. There are more than 350 separate entries in the list : many of these cover a number of scholarships so that the total number of available awards is much greater. The list should be a valuable work of reference for students and educational authorities and is published by H.M.S.O., price $5 s$.

\section{Costantino Gorini Foundation for Dairying, Milan}

A FOUNDATION in memory of Costantino Gorini, the dairy bacteriologist, who died in September 1950 in his native city of Milan, has recently been formed, under the auspices of the Lombard Institute of Sciences and Letters of Milan, for the purpose of assisting research workers engaged in dairy science and technology, especially in the field of microbiology. Periodically, an international competition will be held and a prize awarded for results in improving the production and uses of milk and dairy products in the interest of human nutrition. Entries for the present competition, for which the prize will be 100,000 lire, must be sent in before December 31 , 1952, to the Istituto Lombardo, Via Brera 28, Milan. An entry must consist of a letter of application, supporting reprints of published work and an account of the research work completed since 1949; the reprints and the letter of application may be written in Italian, French, English, Spanish or German, but the account of the work itself must be in Italian or French.

\section{Jaina Legend in Old Gujarati}

A work in Old Gujarati ("The Nalarayadavadanticarita (Adventures of King Nala and Davadanti)", edited and translated by Ernest Bender (Trans. Amer. Phil. Soc., 40, Pt. 4, 1950) is a Jaina version of the Mahabharata story of King Nala and Queen Davadanti. Nala loses his kingdom at dicing to his younger brother and is exiled, taking the form of a hunchback at the command of his father's spirit. After adventures lasting twelve years he is reunited with Davadanti, assumes his natural form and regains his kingdom. The story is used as a discourse on the precepts of the Jaina religion, Nala's misfortunes and subsequent reinstatement being $\theta x$ plained as the outcome of his actions in previous births. The book contains a comparison with the Mahabharata version, notes on metres and grammar, the Gujarati text in English script, and a translation, glossary and bibliography.

\section{Isabelline Shrike on the Isle of May}

IN September 1950 Miss Winifred Flower and Miss M. I. Kinnear observed on the Isle of May a shrike which did not appear to resemble any of the species described in "The Handbook of British Birds". Full details were forwarded to the late B. W. Tucker, who accepted the record as referring to the isabelline shrike (Lanius isabellinus). Later, Sir Norman Kinnear compared this material with specimens in the British Museum and confirmed the identification of what is a species new to the British list (British Birds, 44, No. 7 ; July 1951). The breedingrange of the species Lanius isabellinus extends from Transcaspia and the southern Khirgiz steppes through Turkestan and Mongolia to southern Transbaikalia and Alashan and Ordos in inner Mongolia. Various authorities are in disagreement as to the ranges of the three subspecies $L$. $i$. isabellinus, $L$. $i$. phonicuroides and $L . i$. speculigerus, but agree that the last is found in Mongolia and Transbaikalia. On migration the isabelline shrike travels south-westward through north-western India, Persia, southern Iraq, and southern Arabia to winter in Africa from the Sudan, Abyssinia and Somaliland south to Uganda and Kenya and west to the Lake Chad region.

\section{Acetylene Industry and Chemistry in Germany during the War}

THE Department of Scientific and Industrial Research has issued a booklet entitled "The Acetylene Industry and Acetylene Chemistry in Germany during the Period 1939-1945", by Dr. R. Owens and Dr. A. W. Johnson (pp. 157; London: H.M.S.O., $1951 ; 3 s, 6 d$.$) . This is a substantial$ pamphlet and gives very detailed information on all aspects of acetylene chemistry, in which important advances were made in Germany during the war period. The processes include the thermal cracking of methane and other saturated hydrocarbons, and the manipulation of acetylene under pressure. The chemical industry will undoubtedly be grateful to. H.M. Stationery Office for making available (and at such a low price) a compilation of this size and content.

\section{Proceedings of the International Conference on Low Temperature Physics}

THE Proceedings of the International Conference on Low Temperature Physics held in Oxford during August 22-28 (see Nature, November 10, p. 807) are now available and are being sent out to those who ordered them at the conference. The publication consists of illustrated reports of 106 papers on $\mathbf{1 6 5}$ foolscap pages produced by the 'Rotaprint' process together with a short summary of the discussions. It is of interest to see how prompt publication of this report has been achieved. Fifty reporters, drawn from research workers in the Universities of St. Andrews, Bristol, Cambridge and Oxford and Queen Mary College, London, were used, each of whom was allotted about an hour of conference time. They were asked to write about $350-400$ words, and to choose the minimum number of diagrams, for each fifteen minutes they were 'on duty', and in most cases they were confined to lectures given by people from the same laboratory as themselves. Manuscripts submitted in advance were also dealt with by the reporters on this basis. In this novel way, the organizers of the Conference were able to receive promptly short trustworthy accounts of papers presented, and also adequate reports of the actual discussions, with the result that the present useful summary has been prepared under the editorship of Dr. R. Bowers and produced within three months 